\title{
Capital Accumulation as a Tool for Urban Rent in Turkey
}

\author{
Hazal Ilgın Bahçeci \\ Gazi University, Ankara, Turkey
}

\begin{abstract}
Within the framework of capitalist relations of production and distribution of scarce and precious land resource, production is important in terms of both use and exchange value. Rent, is a product of the creation of surplus value by the investment decisions of the public and private sectors. Market mechanisms and development rights are formed within the framework of capitalist relations of production and the location of urban development in urban spaces and are named of "urban rent". Especially with the process called globalization, urban rent is a vehicle from a position of significant capital accumulation. This is one of the reasons that Turkey's urbanization is considered an unhealthy process as a whole. The urban renewal project started to be implemented rapidly after 1980, in what way urban "transform" stands before us as the most controversial issue in this area. The aim of this study is to examine the case of urban rent in the process of Turkey's urbanization and to reveal the negative impact of this on the relationship between democracy and the city. In this context, the history of Turkey's urbanization and related legislation will only be considered for clarification.
\end{abstract}

Keywords: urban, urban rent, capitalism, urbanization of Turkey, urban democracy

The city represents a form of structure which is mobilised, separated, and geographically concentrated by the surplus value, created by the community. Therefore, the way to understand the dynamics of urbanization is to examine how it passes through the capitalist accumulation process and understand the relationship between urban spaces (Harvey, 2008, p. 2).

In parallel with neoliberal economic policies being implemented all over the world in the 1980s, Turkey has started to see a significant change. It has developed a political understanding that provides the convenience of international large capital investment in urban scale. Due to this progress, the city has become a vehicle of capital accumulation by the change in the nature of capital accumulation and the expansion of the domain. This is how Turkey's cities began to take shape. In this process, the international capital "fund" is as important as the state and local government. However, implementation of public administration has been limited only to pave the way for capital investments and there has been a rapid decline in public investments. Although, the urban space should have been equal and democratic, it has moved away from these qualities to become more poverty-striken, inequal, and injustice habitation. In this transformation, the negative developments were caused by the capital class in cities and the concept of urban rent.

Corresponding author: Hazal Ilgın Bahçeci, Ph.D. candidate, Department of Public Administration, Institute of Social Sciences, Gazi University; research fields: public administration, urbanisation, urban politics, urban democracy, local governments, political economics-public administration relations, environmental problems. 


\section{Rent and Urban Rent}

\section{The Conceptual Framework: What Is Rent and Urban Rent}

The economic theory of rent is defined as an income borne from the scarcity of not only the land but also all kinds of means of production, goods and without labour (Soyak, 2007, p. 41). The rent in terms of our subject, is a certain amount of time to use a piece of land which can be defined as the price paid to landowners by users. There are three different approaches: classical, neoclassical, and Marxist, about the source of land rent as a result of capitalist relations in agriculture. Although classical and neoclassical approaches are not dissimilar, Marxist approach, is borne from their critique. It is the basis of the economic approach used in urban rent studies which picked up speed especially after 1970's.

Rent according to David Ricordo, one of the pioneers of classical economic theory, is a phenomenon mainly based on land productivity. Having different properties of land such as efficiency, chemical and agricultural characteristics, geographic location, and raw material procurement, creates the rent, because of the connection between income of land and land productivity. This rent, which is known as "differential rent", is created by the property. The value of the existing land is determined by the value of goods produced in that territory. The market value of the products is equal to the price of a low yielding land's products, which is associated with the market. In this case, the products of the land provide a more efficient surplus value which underlies the rent. According to Ricardo, population growth and economic development allow the increase of rent. The reason for this increase is associated with an increase of demand for products and the need to use the low yielding land. This situation makes for increase in market prices of products. The rent acquired from the fertile lands is also increased without the rise in production costs (Ricardo, 2001, pp. 39-50).

Differential rent was carried one step further by theories of settlement and location by neoclassical economists. According to neoclassical economic theory, the function of the land market is to put the land into use to provide income to landowners and to make more profit. Basically this theory, which acts as market supply and demand in a particular territory has been shaped by the behavior of economic agents; it focuses particularly on demand in land use. In this context, the demand for urban land is determined by the attractiveness of certain locations for specific uses and transport prices (Ball, 1985, p. 505). The problem with this neoclassical argument is, however, that rent is regarded as a payment to a scarce "factor" (which is a "thing" concept) rather than as an actual payment to people (Harvey, 2014, p. 240).

According to Marxist economic theory, the thing that creates the phenomenon of rent is class relations. The land rent in capitalism qualifies social relations among the three classes formed in landowners, agricultural capitalists (tenants), and agricultural workers. Accordingly, capitalist exploitation relations between capitalist tenants and wage labours are fundamental relations of production. The surplus value created by workers is divided between big landowners and capitalist tenants. In this way, the tenant capitalists get rent at least when making the average profit. According to Karl Marx, rent is the amount paid to the landowner because of the private property on the land. Marx, who makes his rent analysed in the framework of the trilateral relationship between land, land ownership, and capital, divides the Ricardo's differential rent. The rent, formed by land fertility and a land's location, is "differential rent I". The rent, formed by the differentiation is a result of investments which is made by human labour such as improvement to the land. This is known as "differential rent II". The monopoly of private property in land is defined as "absolute rent" by Marx. This is land that cannot be increased in quantity and he refers to this as "monopoly". While demand for land increases, land 
value increases also, which is a result of the fixed-land supply. This forms absolute rent (Marx, 1951, pp. 201-340; Marx, 1991, pp. 751-907).

The concept of urban rent is reached through the implementation of rent policies that apply to agricultural land. Urban land is land that is dedicated to construction and can take advantage of the conveniences and services offered by the city administration. Agricultural land is converted to urban land by setting up substructure and giving development rights. This process is called "production of urban land" (Keleş, 1998, p. 83).

Due to the monopoly of private property on land, both agricultural land-rent and urban land-rent occur as the absolute rent and differential rent in the capitalist economic system. In the production process of urban land, improvements in land associated with development rights and infrastructure services increase the value of the land, and subsequently the rent of land. Possessing certain characteristics of some plots of land; i.e. being situated in close proximity to the city centre, being in a good location in terms of transportation facilities or to be the settlement of the high-income group can cause this urban land to be valued more than others. Thus together with growth in urban spaces, will mean that people who own the land obtain a monopoly power and this power consists "monopolistic urban rent". "Absolute urban rent" consists of in spite of the growing demand in urban spaces, due to the increasing lack of urban land for a variety of reasons. Harvey is of the opinion that class-monopoly rent is best treated as one form of absolute rent (Harvey, 2014, p. 241).

Monopoly rent and absolute rent are becoming more important with the growth and differentiation of the city. "Differential rent" has a meaning in relative space which has been configured by the volume of production in different locations and has been integrated spatially with transportation costs. "The individual and class monopoly rents", stands out based on location, mode of operation, income groups, and steering power in accordance with their interests public decision of rentiers. The dominant position of individual and class monopoly rents is as a result of the capitalist market economy, political and legal process (Harvey, 1993, pp. 160-162).

Marx states that rent, derived from the ownership structure, is the fixed capital interest which may be additional to land rent, incorporated into the land (Marx, 1991). Therefore, understanding the urban rent in the capitalist economic system depends on the interest taken in conjunction with fixed capital (Harvey, 1984, pp. 68-74; Harvey, 1993, pp. 153-194), because the relationship between financial capital and urban lands is constituted by interest. As follows, the price of land is built on the structure which is the sum of the price of other land in its vicinity and the resulting rental income. However, the price of land is not determined by building construction costs or the unpaid labour of workers but by movement of capital in the financial market. In this context, urban rent is not explained by land or what is built on the land. Nor can it be calculated by the profit movement of productive capital. Urban rent can be explained by the relationship between the rental income generated by structure and interest rates (Bedreli, 2007).

\section{Importance of Urban Rent in Capitalism}

The basis of the urban issue is related to the way public consumption means such as housing, education, health, culture, and transport is organised. In advanced capitalism, the concentration of capital and consumption means refers not only to the increasing socialization of consumption but also the fundamental contradiction in the capitalist logic. This contradictory logic occurs from the production and distribution means (Castells, 1982, p. 16). There is a direct relationship between the organization of the urban system and the organization of 
capital. The role of urban space in separating production organisation and shaping social relations is represented in urban structure (Harvey, 1985, pp. 222-223). When the urban structure was established, it affected the organization of production and the future development of social relations. For example, the spatial variation of the urban form affects the income distribution mechanism; by changing the location of economic activity means the change of job opportunities. Changes in the living area bring about changes in housing opportunities. In either case, there is an alteration on transportation costs and finally, changes occurring in the means of transport affect input costs for business opportunities (Harvey, 1993, pp. 86-91).

In this context, the crisis that is experienced in areas such as housing and transport is largely related to any form of organization of urban space and is the result of a kind of connection between human activity and social organization of the material basis of these activities. Castells represents the situation as follows:

Concentration of production and consumption vehicles in economic, technical, social and spatial ways, in fact, corresponds to the logic of centralization of capital and the political management ... Urban crisis arises as a result of the uneven development of activities and regions. Metropolitan areas can only be explained by desert made up of ravaged regions. Overpopulation, lack of open space and the creation of artificial technical environment, are not the inevitable result of technological developments, rather is an expression of the certain kind of social and spatial organization of activities. This relationship is intended to serve the purpose of removing most of the accumulation of capital-whether public or private. Then, the social relations of accumulation that have to be prioritized according to itself, is also a social relationship. (Castells, 1982, pp. 18-19)

This point forces us to examine two important results: The first one is the relationship between urban problematic and capitalist manufacturing type and its contradictions. Urban rent in this relationship is a major player with a large contribution to capital accumulation. Another important result is the social and political outcomes which are created by the relationship in question in urban space. This issue is directly related to the connection between the city and democracy.

The rent and interest on capital relation in the capitalist economic system cause important rent increases that allow the development of capitalism renewing itself. The rent values and the capital asset are increased by urban growth. Capitalist mode of production, the existence and dynamics of capital accumulation, and developing the relations of production in this context are necessary for existing urban rent. Harvey explains this relationship via the crisis of capitalism theory. Capitalism is a system based on profit and competition, which always renews itself via competition among capitalists, excessive use of labour in production, and excessive accumulation created by the resulting profits. Increasing capitalist profits can be possible by shortening the time taken for goods to be produced and released to the market and the time in circulation. This forces capitalists to create technological innovations; investing in new machines, developing and implementing time-saving techniques of production and management, extending the working time, ensuring the increase of production by accelerating the pace of social and urban life (Merrifield, 2002, p. 142). Excessive accumulation results from the inability to convert the investment of accumulated capital. All these processes are referred to as the primary loop of capital. The system goes into crisis as a result of the inability to turn invested capital into profits. The way to solve the emerging crisis is shifted from the first cycle to the second cycle of capital investments; which means directing a significant portion of the capital to the built environment. In this way, capital temporarily overcomes the excessive accumulation problem of capitalism by producing the built environment within the framework of its own logic. Therefore, the investment in the built environment is seen as a way to assure stability during periods of crises in the capitalist economy (Şengül, 2009, p. 20). 
According to Harvey, fluctuations in the rate of profit imposed a powerful financial order on the space by putting land into orbit of accumulation, supply and demand of money capital. The rise and fall in the rate of profit, means that the land market declines and fluctuates in the city. Offering better profits from rising rents of land to other sectors of the economy and being able to obtain financial capital in reasonable profit rates direct investment into the real estate market. It encourages action on urban land for maximum profit and after a while, it will reveal an appearance of looted spaces due to excessive investment. While some urban areas keep out of investment with excessive investment, there are excessive investments in some areas so uneven geographical development increases. "The most striking examples for this are calamity areas in urban centers. Created poverty and spatial collapse in these areas are again converted into a vehicle providing rent with the urban renewal process" (Şengül, 2009, p. 310). This kind of speculation on urban land is necessary for capitalism to get rid of economic crisis which repeated by its nature and to always renew itself in this way (Merrifield, 2002, pp. 147-148).

As noted earlier, the shortage of urban land is the most important cause of the formation of urban land rent. Rent, is borne as a result of the seizure of these lands by the owner of private property. Rents and land prices steadily rise because of construction sites in large urban areas and industrial centres with the seizure of located land in central or convenient locations by the people. Building owners burden land rent to tenants due to rack rent and land prices rise. On the other hand, urban land rent is separated from other rent types because of its location. However, it is worth noting here, relationships in urban land-rent cannot be solved with just tenancy relationships because of letting value cover a larger financial amount than land rent which is the main element constituting the lease (Turan, 2009, p. 55).

According to Harvey, absolute and monopolistic rents participate in the production costs especially in today's big cities and these costs determine to use. Therefore, highest rent areas are in use by commercial activities whose productivity cannot be measured. But we must not forget that the least productive activities in society have the highest marginal productivity in terms of location. This paradox cannot be solved with the marginal productivity of land. However, it can be solved by analysing the process that causes implementation of absolute and monopoly rents (Harvey, 1993, pp. 172-173).

\section{Urban Rent in Turkey}

The process of formation and distribution of urban rent in Turkey reflects a unique feature. This is because, in general the property relations, in private landowning relationships are different especially from the European community. From the 18th century, in European countries, production of land as a meta and sharing the emerging rent have been provided within the framework of private property between capitalists and the amount of capital transferred to land. In Turkey, this process takes place in the form of private ownership of land which is subject to state ownership. In other words, while in question is differential rent in the European societies, in question is absolute rent in Turkey.

These differences are based on property relations in the Ottoman Empire. Feudal social structure in Europe fell into decay with the rise of the bourgeois class and the commodification of land and was replaced by capital ownership. Capital accumulation over land took place in this way (Yırtıc1, 2011). In the Ottoman Empire, land ownership of the most basic means of production is completely owned by the state. Lands were given to soldiers and local administrators as "timar". Mesne lord had to fertilise these lands, train soldiers, pay taxes and was obliged to send trained soldiers to the war when the time came. Mesne lord is not entitled in any way to 
save land. Therefore, mesne lord was not the property owner. At this point, it is not possible to talk about a savings or private property (Divitçioğlu, 1981, pp. 51-54).

\section{Capital Accumulation Process Oriented Trade: Between 1923-1954}

The Ottoman Empire was cumbersome to reproduce the land as a commodity in its structure of centralist land ownership. Nineteenth century Ottoman modernization, has adopted the land as a commodity on the one hand, it has introduced several restrictions to collection and trade of land ownership in private properties. This cumbersomeness about the reproduction of land has continued after proclamation of the Republic in 1923 and subsequently implemented modernity project. The modernization project of the new regime tried to set up a national market and integrate with world markets. While providing economic mobility by distribution of land that is key to the accumulation of capital, during the Independence War and in the early years of the Republic, minority groups were obliged to leave the country and the amount of state land increased. In later years, efforts to distribute land to the peasants were never enough and fair; they often resulted in only certain groups of the winning rent (Tekeli, 2011a, pp. 106-110; Yırtıc1, 2011).

After the founding of the Republic, new regime administrators, who wanted to create a modern society and a new nation state, adopted the creation of the national bourgeoisie as the primarily economic policy. However, there was not enough capital accumulation, labour, and the market conditions. Also, as a result of the mode of production, there were production relations based on land in a significant part of the country. In this context, the rate of industrialization of the country was at a level almost negligible; foreigners had all the modern factory, bank, and transport jobs which are few in number. The main reason for this view is the lack of capitalist property system and associated relationships. In these circumstances, the creation of the national bourgeoisie and the construction of the national economy have become the first target. In this basic goal, the speed of economic growth and industrial development was increased by the continuation of rail infrastructure investments and policies, which continued until the end of the 1930s, and Industry Promotion and Customs laws dated 1927 and 1929 (Kuruç, 1999, pp. 22-23).

In 1929, the Great Depression has led Turkey to the start of an important process in terms of economic policy. During the 1930s, basic economic policies of Turkey can be specified as "introverted rapid industrialization under the leadership of state". The absence of the national bourgeoisie has necessitated statism. During this period, the state's official policy was based on an import substitution applied by state enterprises and local input. These policies have been applied throughout the 1930s, but neither dissolution of social relations based on agricultural production nor was the promotion of industrial investments achieved. In 1939, with the onset of World War II to be a limitation on imports, having led to the realization of a major breakthrough in the area of domestic industrial production, in 1940. However, after 1945 with the re-opening of world markets, the decline started again.

After World War II, the entire world entered a new process led by the US, Turkey has got its share, too. In 1946, for the adoption of Turkey's IMF (International Monetary Fund) membership many economic applications, such as devaluation and trade liberalization have been accomplished. It has been observed that the priorities of the statist period were abandoned in the report prepared in 1947 to take the Marshall Aid program. From this period, liberal laws about foreign capital began to be brought into force.

The 1950s was at the forefront of economic growth and national income growth. The agricultural sector has improved owing to the widespread use of the tractor in the second half of the 1940s until 1955. Until the 
1960's, important infrastructure investments can be reported with investment in urban areas via growing urbanization in line with the irrigation, energy, and communication sectors. Road investments supplanted the railway investments, which was invested before the 1940, after these dates (Eroğlu, 2007, pp. 65-70; Gülalp, 1993, pp. 30-33).

The establishment of the Republic of Turkey and the process of nation-states, was a modernization project. Therefore, such a modernity project was an urban development project. Priority target for the young republic was planning of the new capital of Ankara in the middle of Anatolia in a way befitting the newly established Republic. Republican bourgeoisie and bureaucracy wanted to develop Ankara in a nationalist way. The modern city that would be established in this regard was loaded with a charge of instrumental function (Tekeli, 2011b, p. 308). In this context, the laws and practises for Ankara's zoning and planned development were spread across the country after a while. So, Ankara has been a pioneer of urbanization in Turkey.

During this period, due to Turkey's absence with a combination of capital accumulation to ensure the progress of industrialization and urbanization in this period, the only significant progress was achieved in urbanization in Ankara. In this period, the role of the structural foundations was laid for the small entrepreneur in urban development area, speculation has not emerged yet in the real sense of urban land. During this time, urban rent was shared between bureaucrats and middle class (Yirtic1, 2011).

During this period, one of the most important laws enacted in terms of urban rent was the Municipal Building and Roads Law No. 2290 issued in 1933. This law had an obligation to all municipalities making zoning plans and has given authority to approve development plans made to Ankara Directorate of Development. This article showed that the state sought to generate income from urban rents instead of operating areas in its own property. The founders of the new regime have benefited in strengthening the link between the immovable property ownership and wealth accumulation because of poverty in Turkey. Therefore, the encouragement of land speculation by the state was discussed in this period (Ak1n, 2007, pp. 94-95). The Real Estate and Orphans Bank was established for purposes such as opening long-term, low-interest credit, production and trade of construction and building materials in 1926. It was transformed into Real Estate Credit Bank in 1946. The Bank's objective to produce affordable housing had not reached success. Houses were built for upper income groups. Multi-storey and spacious apartments blocks began to take the location of the garden house (Tekeli, 1996, pp. 29-31). It has been promoted to become homeowners middle class by providing the state with cheap land supports until the middle of 1950. It has escalated the demand for urban land through the variable rates of inflation, and economic growth in the global economy (Öncü, 1988, p. 41).

Building Construction Incentive Act No. 5228 issued in 1948 transferred lands from state ownership to municipalities to encourage the construction of buildings. This in return enabled citizens and cooperatives to build houses. This initiative has encouraged much speculation in the building industry and in this way, publicly owned urban land has largely passed privately owned. Building Construction Incentive Act Law No. 6188, which was a synthesis of the Law No. 5218 and No. 5228 enacted in 1953, has facilitated the transfer of public land to the municipality. The main goal of legislating this law was to prevent the construction of the slum by giving cheap housing areas of municipal planning to needer. But it failed in this regard; the law has accelerated the process of apartment blocks which provided contractors new rents (Tekeli, 1996, pp. 91-92). These laws have encouraged speculation. It has caused to pass through private property urban lands in public ownership and the increase in the change of goods between private property owners. In this way, urban lands have been one of the most profitable investment areas across the country (Akın, 2007, p. 98). 


\section{Capital Accumulation Process Oriented Industry: Between 1954-1980}

Between the years 1954-1961, the ruling Democratic Party began to implement economic policies of import substitution for stabilising of the decreasing rates of imported consumer goods which were manufactured by state investment. Investment areas have changed along with changing economic policies; applications that gave priority to industrial investment in previous period have ended. Thus, the country's economy was trapped in the domestic market prior to the war, which began the process of international expansion especially with an emphasis on modernization in agriculture (Tekeli, 2011a, p. 116). This process is briefly expressed as the abandonment of model mainly based on the accumulation of agriculture and trade capital and the transition to a model based on the accumulation of industrial capital for the domestic market.

The military government that came to power after the military intervention carried out in 1960 adopted the model of import-substitution industrialization as a formal development policy. It has accelerated commercial capital as a productive capital by 1960 military intervention. Including in particular the industrial sector has achieved a high growth rate until 1977. In this way, a part of the commercial capitalists comprehended the importance of being productive capitalist through the rapid development of productive capital in the country. In other words, it showed that they understood the importance of growth by creating surplus value directly (Ercan, 2002, pp. 58, 62).

Specific growth rates have succeeded through the practice of an import substitution model until the end of the 1960's. After this year, the first signs of currency-induced economic crisis began. Western institutions, as a result of the exacerbation of the external debt problem, have suggested giving up over-valued exchange rate policies and taking measures to encourage exports to Turkey. However, these measures could only postpone the crisis. After a while, the possibilities of capital accumulation for the domestic market have been consumed. In particular, access to saturation point of the durable goods invested in the domestic market has necessitated new investment for productive capital. At this stage of the accumulation of capital, the inevitability of the unequal articulation with the world economy has begun to emerge as a structural reality for capital which consumed market and investment opportunities for durable consumption. The "integration with the world economy" means to create more surplus value by capital accumulation channels for external markets or the redistribution of the surplus value (Ercan, 2002, p. 69). In this way, the transition to a new export-oriented model by leaving import substitution industrialization model has required new applications in the economy, the change in development strategy and a new restructuring of the economy for the accumulation of capital. The restructuring has created a new network of relationships between the various sectors of the local economy and the creation of new forms of integration with the world division of labour. This transformation means changing the entire layout which was established in the 1960's, however it was impossible to achieve in terms of populist democracy (Gülalp, 1993, pp. 40-41). The new order required for "integrating with the world economy" will be established after the military coup in 1980.

The 1950's in Turkey was a time where urban problems began to emerge especially in big cities. The reason for that was the rural-urban migration process which began as a result of the modernization of agriculture applications. This practice led to the formation of excess labour in rural areas.

During this period, the lack of planned urbanization has basically two main reasons: Firstly, the state-owned land that was not distributed in a fair way could not be included in economics. There were no legal and financial arrangements to convert from state-owned land to urban land. Secondly, scarcity rent which is the 
result of imported goods restricted by quotas and licensing became field of interest for big capital as a result of the adoption of the economic policy of the state of import substitution industrialization model results, whereas distribution of the surplus income derived from urban development and urban regeneration was settlement medium and small-scale entrepreneurs. Consequently, two separate housing production models came into existence, legal and illegal. The legal being "property development", is specific to Turkey, and the illegal is in the form of slums (Yirtic1, 2011).

The number of slums in the cities has increased rapidly as a result of uncontrolled migration and rapid urbanization. The slums built until 1980 can be divided into three groups by considering the conversion of spent use and in terms of the exchange values: First one covers the period until 1960. During this period, slums have emerged as a result of the poor who have migrated from the countryside to the cities trying to solve the housing needs. During this period, it was not common practice to rent slums. Families that have stayed themselves in the slums could manage to build on the public land. The second period covers the years between 1960 and 1970. During this period, the slums have become a meta which was built to benefit of the owner and raised the rate of labour hired. In the third period after 1970, the slum-making process has been commercialized completely. Slum companies, which provide land to the poor, find the construction materials and build the slum and put it up, have emerged (Keleş, 2015, pp. 536-537). Slums became legalised thanks to the policies carried out. The amnesty law for the slum was issued four times in the process from 1960 until 1980. In a sense, the state that could not stop building slums has chosen the path of reconciliation with the slum-owner (Şengül, 2009 , p. 82). The mass migration from rural areas to urban areas meant cheap labour. Costly infrastructure investments to be made in slum areas mean the limitation of the funds allocated to the industrial sector. Namely on the one hand, the state has been reluctant to bring about urban services for slum areas with populist policies; on the other hand it has enacted many amnesty laws for the legalization of slums. In this way, the slum was transformed into an investment vehicle.

The legal housing needs of the middle class were supplied with "being property development" in the same period. This model envisages the creation of differential rent and over this, the provision of capital accumulation by medium and small entrepreneurs via capital investment on private property. Also in this system, entrepreneurs who do not have sufficient capital accumulation do not have to invest capital for the land by committing to providing a portion of the housing to be made to the landowner. Sales of housing from the more basic construction ensure the investment in construction without the need for pre-capital accumulation. Also, the unskilled labour reduces the construction costs. "Being property development" has been an important model in the transformation of urban land until the 1980's (Yurtıc1, 2011).

During this period, important institutional and legal arrangements were made to keep peace with the transformation of the entire world. One of them was Reconstruction Law No. 6785 issued in 1956. On the one hand the law contains detailed regulations on planning principles; on the other hand it carries flexible provisions on urban formatting. Zoning controls have been allowed outside the municipal boundaries for the first time with this law. Undoubtedly the most important reason for this arrangement was the increase in the period of urbanization and speculative activities stayed out of municipal boundaries to stay out of the zoning control. In addition, detailed regulations that prevent the construction of buildings in violation of zoning have been introduced (Tekeli, 2011a, p. 118). Law No. 6785 has a content that urban services which are not profitable undertaken by the government, will hinder to shift capital to productive investment and the urban rent that allows to support capital accumulation, the low level of industrial capital accumulation keeping the 
speculation that might affect negatively and aiming to be under control the urban rent. If we look closely, the content and the process of capital accumulation period overlap one-to-one (Akın, 2007, p. 109).

The state-owned land outside the municipal boundaries has also granted the opportunity to be transferred to municipalities by the Law No. 7367 issued in 1959. Thus, more lands were provided to open up for speculation (Tekeli, 2011a, pp. 118-119). In addition, within the framework of the welfare state process, Ministry of Construction and Housing was established for the purpose of urban problems to be solved by the state in 1958. The Land Office has been established under this ministry in 1969.

Since the mid-1950's, investment has been directed to infrastructure as a result of the acceleration of import substitution industries to the state funds in conjunction with state policies. Low labour and inflation has enabled the continued development of the housing sector. Private savings have seen the housing construction and real estate values rise. The Ownership Law enacted in 1965 has led to the fixed middle income groups investing their savings in housing or land and has made them gain big income. The large increases in urban land prices have occurred after this law because of the increase about the demand of having a house together in middle class. "Construction return for flat" has become widespread with property ownership. That has accelerated the apartment blocks process, as well (Akın, 2007, pp. 112-113).

\section{Outward Export Oriented Capital Accumulation Period: From 1980 to the Present Process of Globalization}

The most important economical transformations of this period are the abandonment of import substitution industrialization model and adoption of outward export-oriented development. Profit rates providing expanded reproduction of the accumulation of capital have entered a downward trend since the early 1970's due to the inadequate increase of labour productivity and the growing rate of organic composition of capital compared with the mass of created surplus value. The capacity utilization rate in industry has decreased and resources were directed from productive investment to the speculative field. In short, concentration and devaluation of capital as a result of increasing contradictions in the production process has led to clogging of the accumulation process. In this way, one of the structural crises of capitalism has emerged. Unemployment and inflation rates have risen steadily due to the crisis of Keynesian economic policies which were implemented until the 1970's all over the world. States have found a way out of this economic crisis by implementing the policy of Neoliberal economic policies. Through this policy, excessive accumulation of the money will be prepared to evaluate conditions on a global scale to prevent the depreciation of productive and commercial capital in certain areas (especially in the early capitalist countries). Therefore, the previous labour and supervision of the manufacturing process were redefined by audit forms that facilitate the flow of capital between countries. The hegemonic position of the social relations of capital has been further strengthened as a result of these policies (Ercan, 2002, pp. 52-53). The conditions of this transformation have been prepared by a military intervention on September 12, 1980 in Turkey. After this date, the statist policies applied in the economic field have ended. Import substitution has been virtually abolished and economic arrangements appropriate to the new process have been brought by the series of decree and, also known as "January 24th Decisions", adopted on January 24, 1980.

It was necessary to end the protectionist policies of national economies which limited the movement of capital for the creation of a world market that allows free international movement of capital. In this process, the state is left active role in the economy; it has transferred economic investment and social consumption services 
to the community, local governments, or non-governmental organizations. Fields that were left by the state have been left to the capital (Ak1n, 2007, p. 123). While the rate of this situation increases, naturally, the profit of capital directs the production process and it increases spatial inequalities as well. During this period, the metropolitan centers increase the weight on the formation of the total capital accumulation and distribution by revenues increased foreign relations and foreign trade. Also, other large cities have entered into a period of rapid growth (Eraydın, 1988, p. 150). In this way, new phase of capitalism called globalization has also caused to make a serious transformation of cities with the change of economy and politics. The interest in the fierce competition has transformed by making all labour markets, labour processes, products and consumption patterns more flexible in parallel to flexible transformations in the physicality of the city. New commercial buildings, flashy hotels, coastal caves, sports stadiums, shopping and cultural centers with eye-catching architectural style have sprung up and have replaced the old drab shipyards, mills, drums, and warehouses. The government has withdrawn completely from public services. It has left developer investments to private capital that makes the second cycle of capital. The result has been the settlement of trade and capital city attractions in a powerful way (Merrifield, 2002, p. 310).

In the period after 1980, the investments in urban areas have been made by tenders given to private sector, in a sense, urban investments have become an important vehicle of transferring funds to the capital (Eraydin, 1988). After the settlement of capital accumulation of the city center and the urban rent became an important source for the accumulation of capital, private capital has begun to take place in structured environment with direct investments. Especially since the beginning of the 1990's, huge shopping malls, five-star hotels, and skyscrapers have started to become an integral part of the big cities. In this way, the city which is the tool of speculative profits since the first period has become a more central position than ever as a strategic commodity (Şengül, 2009, p. 141).

The reflection on urbanization in Turkey of the neoliberal economic policies transition can be expressed as "the introduction of capital movements to steer the process of urbanization". From this period, "the capital established the hegemony to urban spaces" (Şengül, 2009) has been the main actor in the process of urbanization since 1980's. With that process, the cities have become places where were experiencing unemployment, imbalances in the distribution of income, socio-spatial segregations, lack of public service and social justice.

The opening of new investment channels in the capital to solve the crisis of the accumulation of the late 1970s has led to new regulations. One of these regulations was committed planning task to municipalities by the Settlement Law numbered 3194 in 1985. The law has authorized the planning applications and construction activities to municipalities in the boundaries of the adjacent area; it has given to the governor in other areas. The value of the assets transferred to the private sector from public sources and gathered in private ownership has not been returned to the public by any means.

Other important regulation is the Housing Law numbered 2487 issued with the aim of encouraging the production of "social housing" in 1981. Mainly, it was intended to provide convenience for the development of housing areas that began to occur especially in large cities by transforming the land into urban land in the urban periphery. It was also intended to accelerate the flow of capital in this way. Then, Mass Housing Administration (TOKI), a new initiative for accelerating the flow of capital and to support the accumulation of capital through urban rents, was founded in 1984. The Housing Development Administration of the President provided the opportunity of acting autonomously and flexibly with Housing Law No. 2985 issued in 1984. 
Production of housing estate has been initiated by housing cooperatives and major housing construction companies based on Housing Law's articles which encouraged the largest construction companies in the production of housing since 1985. Directorate General Land Office has been abolished and its powers are transferred to the Public Housing Administration by the Law No. 5273 which was enacted in 2004. Some provisions of the Housing Law No. 2985 were amended by this law. According to this change, TOKI was authorized to push and make amendments to the development plans of all sizes in areas where slum transformation projects would be implemented. After this law, the state entered an intense for-profit housing production activity as a result of coexistence of the TOKI and private sector (Akin, 2007, pp. 130-135).

The year of 2004 is the beginning of the legal process where the experience of urbanization in Turkey began to take shape by the urban transformation projects. The underlying model of urban transformation projects in the 1990's, within the framework of applicable Municipal Law and the Slum Law, has been based on the land rent created under the leadership of the public (Keleş, 2012, p. 5). Turkey's urban regeneration in the legal process has begun with "The Law of North Ankara entrance urban regeneration project" in 2004. Municipalities have been given authority about the urban transformation by the Municipal Law No. 5393 issued in 2005 .

The period after 2010 can be considered as the golden era of neoliberal urban concept in Turkey (Görmez, Altınışık, \& Bahçeci, 2013). The municipal authority for urban regeneration has been extended further by an amendment to the Municipal Act in 2010. Mainly, urban regeneration approach of this period can be understood with three laws. The Law Decree on the organization and duties of Ministry of Environment and Urban Planning No. 644 is the first. This regulation has been subject to some changes later by Law No. 648 . Secondly, the Law About the Conversion of Areas Under Disaster Risk No. 6306 and lastly, the Municipality Law No. 6360.

The Ministry of Environment and Urban Planning was established by the Law No. 648 and Decree-Law No. 644 and this ministry has been given a wide planning authority to include urban regeneration areas. In this context, Directorate General of Spatial Planning has been established to open the way for urban regeneration applications and it has been blessed with a new type of plan with the name of Spatial Strategy Plan.

The urban regeneration's purpose of protection against this kind of risk areas for natural disasters has been put in front of all other goals of urban regeneration by the Law on the Transformation of Under Disaster Risk Areas No. 6306 issued in 2012. In this state, the law dealt with in the narrow sense of regeneration. In other words on one hand, this law has narrowed down the meaning of the concept of urban regeneration and has limited it with the areas that are at risk of destruction, on the other hand, geographical area to be covered the application has been expanded by this law (Keleş, 2012, p. 7).

Finally, urban areas and rural areas have been incorporated in 30 provinces by the new Law No. 6360 on Metropolitan Municipalities which has come into force in 2013. In this way, the metropolitan municipalities were authorized to carry out urban regeneration projects.

Production and sharing of urban rent in Turkey has accelerated together with exclusive development rights and new financing methods in order to meet the demands of large-scale projects since the beginning of the 2000's. The public and private sector partnership in urban regenerational projects has been seen only in urban centers which are engaged in urban restructuring and where the value of the rent is high. These urban-regeneration projects have become "surplus sharing projects". Differential rent transfers the ownership and allows capital investment. Primarily by changing the position of the high rents space plan is converted to 
absolute rent after performing the sale of privileges provided in the bidding process. In other words, differential rent and absolute rent are not shared among all of the society; instead they are transferred to the new landowner. However, intensive construction and infrastructure costs are recompensed by the state due to the privileges that are provided with planning. This situation leads to harming the public and damaging the principles of social justice (Turan, 2009).

\section{Conclusions}

In Turkey, urban rents are seen as an important vehicle of articulating global capitalism. This has been used extensively for the past 20 years by the implementation of urban transformation. The main feature of these applications is being carried out in the form of "housing programs" under the leadership of central government. The purpose of obtaining the value of the change in urban space is to preclude the goal of enhancing the public interest in the production of housing. Urban land, which means the increased value of urban land rent, either in whole or in a substantial part of the municipality or the state's coffers; therefore, it is a need to return to the principles of social justice in urban areas. However, in the implementation of urban transformation projects in Turkey, urban rents are only transferred to the capital without social justice principles. Most of the society suffers from the sharing method of urban rent instead of providing benefits. Urban conflicts are increasing in this way. As a result, on the one hand the city's cultural, historical, and natural values are destroyed, on the other hand cities are being spaces of spatial inequalities and urban poverty. In this way, relevant groups have created urban spaces by alienating the city's increasingly impoverished groups in the city's high-rent regions. Unsanitary settlements and urban poverty are ignored in the rest of the fewer cities' rents.

Another feature of the urban transformation projects in Turkey is that they are often carried out in order to revive the country's economy. Although real estate investments are crucial to float the country's economy, these investments, when exceeded, lead to the new crisis of capital accumulation, major economic crisis as a result of a vicious cycle that took place in the framework of capitalist relations of production. Without industrial policy which is independent in terms of input goods and prioritised industrial production, request for the establishment of economic growth and stability is a request that is too far from scientific and reality.

Urban land in Turkey is seen as a producible commodity, in this context, the benefit of capital is at the forefront rather than the benefit of the public interest. In parallel, urban policies are shaped by the demands of capital accumulation, theoretical and legal framework for development is created as well.

The natural consequence of this is that the development process is shaped according to the format of capital accumulation and only a small segment of society is able to benefit. Subsequently, it seems impossible even to think about concepts such as urban rights, urban participation, urban equality, and urban justice. So, firstly, there is a need for a wholesale policy change in the allocation process of urban rent to be able to talk about democracy in urban space or to talk about the democratization of city administration.

\section{References}

Akın, E. (2007). Kentsel gelişme ve kentsel rantlar: Ankara örneği (Urban development and urban rents: A sample of Ankara). $\mathrm{PhD}$ dissertation, Department of Political Sciences and Public Administration (Urban and Environmental Sciences), Institute of Social Sciences, Ankara University, Ankara.

Ball, M. (1985). The urban rent question. Environment and Planning A, 17(4), 503-525.

Bedreli, N. (2007). Rant teorisi ve tekelcilik: Rant teorisi üzerine bir deneme (The theory of rent and monopolism: An essay on the theory of rent). Retrieved from http://www.yayed.org/id192-yayed-gorusu/rant-teorisi-ve-tekelcilik.php 
Castells, M. (1982). City, class and power. New York: St. Martin's Press.

Divitçioğlu, S. (1981). Asya üretim tarzı ve osmanlı toplumu (Asian style manufacturing and Ottoman society). Kırklareli: Sermet Matbaas1.

Eraydın, A. (1988). Sermaye birikim sürecinde kentler (Cities in the process of capital accumulation). Dergi, 5, 133-153.

Ercan, F. (2002). Çelişkili bir süreklilik olarak sermaye birikimi (1) [The capital accumulation as a contradictory continuity (1)]. Praksis, 5, 25-75.

Eroğlu, N. (2007). Atatürk dönemi iktisat politikaları (1923-1938) [Economic policies in the Atatürk period (1923-1938)]. Marmara University Journal of I.I.B.B.F, 23(2), 63-73.

Görmez, K., Altınışık, U. H., \& Bahçeci, H. I. (2013). Muhafazakarlık, neoliberalizm, kentsel dönüşüm ve kimliksiz kentler (Conservatism, neo-liberalism, urban transformation and unidentified cities). In The book of KAYSEM (symposium of public administration)-8: Local governments and urban politics from theory to practice (pp. 355-360). Ankara: Sarıyldiz.

Gülalp, H. (1993). Kapitalizm, sinfflar ve devlet (Capitalism, social classes and the state). İstanbul: Belge Yayınları.

Harvey, D. (1984). The limits to capital. Oxford: Basil Blackwell.

Harvey, D. (1985). The urbanization of capital. Oxford: Basil Blackwell.

Harvey, D. (1993). Social justice and the city. Oxford: Basil Blackwell.

Harvey, D. (2008). The right to the city. Retrieved from http://davidharvey.org/media/righttothecity.pdf

Harvey, D. (2014). Class-monopoly rent, finance capital and the urban revolution. Regional Studies, 8(3-4), $239-255$.

Keleş, R. (1998). Kentbilim terimleri sözlüğü (Dictionary of urbanology terms). Ankara: İmge Kitabevi.

Keleş, R. (2012).Türkiye'de yerel yönetimlerde kentsel dönüşüm (Urban transformation in local governments in Turkey). Public Administration Institute for Turkey and the Middle East (TODAİE) workshop of urban transformation process in local governments in Turkey. Ankara.

Keleş, R. (2015). Kentleşme politikası (Urbanization policy). Ankara: İmge Kitabevi.

Kuruc, B. (1999). Cumhuriyet döneminde iktisat politikaları üzerine gözlemler (Observations on economic policies in the Republican era). In Z. Rona (Ed.), International conference on overview of the 75 years of the Republic of Turkey: Statement 1923-1998 (Vol. 2) (pp. 21-32). İstanbul: Tarih Vakfi Yayınları.

Marx, K. (1951). Theories of surplus value. London: Lawrence \& Wishart.

Marx, K. (1991). Capital: A critique of political economy (Vol. 3). London: Penguin Books.

Merrifield, A. (2002). Metromarxism: A Marxist tale of the city. London: Routledge.

Öncü, A. (1988). The politics of the urban land market in Turkey: 1950-1980. International Journal of Urban and Regional Research, 12, 38-64.

Ricardo, D. (2001). On the principles of political economy and taxation. Kitchener: Batoche Books.

Şengül, T. (2009). Kentsel çelişki ve siyaset: Kapitalist kentleşme süreçlerinin eleştirisi (Urban conflict and politics: Criticism of capitalist urbanization). Ankara: İmge Kitabevi.

Soyak, M. (2007). Rant ve rant aramanın ekonomi politiği (Rent and political economy of rent-seeking). Bilim ve Ütopya (Journal of Science and Utopia), 160, 41-46.

Tekeli, İ. (1996). Türkiye'de yaşamda ve yazında konut sorununun gelişimi (The development of the housing problem in the literature and in the life in Turkey). Ankara: TOKİ.

Tekeli, İ. (2011a). Modernizm, modernite ve Türkiye'nin kent planlama tarihi (Modernism, modernity and history of urban planning in Turkey). İstanbul: Tarih Vakfi Yurt Yayınları.

Tekeli, İ. (2011b). Türkiye'nin kent planlama ve kent araştırmaları tarihi yazıları (Writings on research of Turkey's urban planning and urban history). İstanbul: Tarih Vakfi Yurt Yayınları.

Turan, M. (2009). Türkiye'de kentsel rant: Devlet mülkiyetinden özel mülkiyete (The formation and the division of the urban rent in Turkey: From state ownership to private ownership). Ankara: Tan Kitabevi.

Yırtıcı, H. (2011). Türkiye'de bir sermaye birikim aracı olarak toprak rantı ve mekanın dönüşümü (Ground rent as a tool for capital accumulation and the transformation of space in Turkey). Retrieved from http://www.mimarlikdergisi.com/index.cfm? sayfa $=$ mimarlik $\&$ DergiSayi $=376 \&$ RecID $=2802$ 